\title{
Türk - Amerikan İlişkileri: Suriye Gerilimi*
}

Turkish-American Relations: Syrian Tension

Mehmet Nur ÇELIKASLAN

Dr. Öğr. Grv., Gaziantep Üniversitesi, Sosyal Bilimler MYO, phdcelikaslan@gmail.com https://orcid.org/0000-0002-0189-6836
Makale Başvuru Tarihi: 18.07.2021

Makale Kabul Tarihi: 27.08.2021

Makale Türü: Araştırma Makalesi

\section{ÖZET}

Anahtar

Kelimeler:

Türk - $A B D$

İlişkileri,

Suriye Meselesi,

Gerilimler,

Bu araştırmada liberal değerleri paylaşan iki müttefik ülke Türkiye ve ABD arasında yaşanan gerilimlerin ve tarafların çatışan çıkarlarının kavramsal çerçeveye hangi açıdan meydan okuduğu, Suriye gerilimi örneğinde sergiledikleri yaklaşımlar üzerinden incelenecektir. Bu araştırmanın amacl, özellikle 2002-2020 döneminde Türkiye ve ABD arasında küresel gelişmelerden kaynakl farklılaşan ulusal güvenlik kaygılarl ve çıkarlarının neden olduğu Suriye gerilimi konusunda, sorunun çözümü için, tarafların liberal bir yaklaşımı mı yoksa realist bir yaklaşımı mı tercih ettiklerini incelemektir. Bu çerçevede, nitel araştırma desenlerinden vaka çalışması türlerinden açıklayıcı/tanımlayıcı durum yöntemi kullanılmışıır. Bu yöntemde veri toplama amacı ile kullanılan araçlardan olan mülakat yöntemi ve doküman incelemesi ile veri toplanmıştır. Araştırma sonucunda İki ülke arasında gerçekleşen Suriye geriliminin ABD tarafinın problemleri liberal bir yaklaşımla müzakere ederek çözmek yerine, realist yaklaşımı benimsediği bir olay olduğu tespitine ulaşılmışıtır.

\section{ABSTRACT}

Keywords:

This study investigates how the tensions between and the conflicting interest of the two allied countries Turkey and the USA sharing liberal values challenge the conceptual framework by looking at their attitude during the crisis of Syrian tension. The current study aims to explore if the parties go for a liberal or a realist approach to resolving the matter over the visa permits brought about by their interests and concerns for national security resulting from the global developments between Turkey and the USA between the years 2002-2020. It is based on the explanatory/descriptive approach under the case study as one of the strategies of the qualitative research designs. The data were collected through interviews and document analysis. The findings show that the USA went for the realist approach rather than a liberal one based on negotiations in resolving matters such as the matter over the Syrian tension.

Turkey - USA

Relations,

Syria Event,

Tensions,

* Bu makale, yazarın 2021 yılında hazırladığı ve Hasan Kalyoncu Üniversitesi Sosyal Bilimler Enstitüsü tarafindan kabul edilen "Ak Parti Dönemi Türk Dış Politikası: Türk - Amerikan İlişkileri Örneği (2002-2020)" adlı doktora tezinden yararlanılarak hazırlanmıştır. 


\section{GIRISS}

Türk-Amerikan ilişkilerinin 2002 sonrası yaşanan 1 Mart tezkeresi ile başlayan ve günümüze kadar devam eden dönemi, "Iliş̧kinin temellerinin sarsıldiğ evre" olarak nitelendirilebilir. 2002 sonrası dönemde 1 Mart Tezkeresi ve ardından yaşanan Süleymaniye hadisesi, Türkiye'ye yönelik silah ambargoları, Halkbank gerilimi, vize gerilimi, Rahip Brunson olayı, Suriye Meselesi ve Türkiye'nin S-400 alımına yönelmesi gibi olaylar ve gerilimler sonrasında iki ülke ilişkilerinin diplomasi kanalından çıkmakta olduğu görülmüştür.

Suriye iç savaşı ve güvenli bölge sorunu Türk-ABD ilişkilerinde AK Parti döneminde yaşanan sorunların bir başka örneği oluşturmaktadır. Suriye meselesi ABD ile gerilimler yaratmanın ötesinde Türkiye'yi bulunduğu coğrafyada rahatsız eden bir konu olarak geçmişten beri varlığını devam ettirmiştir. İki ülke arasında son dönmede yaşanan sorunlar içerisinde ulusal güvenlik kaygıları nedeniyle Türk tarafını en çok rahatsız eden sorunun Suriye meselesi olduğu alana ilişkin pek çok uzman tarafından dile getirilmektedir.

Türkiye-Suriye ilişkilerindeki gerilimlerin ve problem alanlarının geçmişi 2011 yılında patlak veren Suriye Savaşı'ndan çok daha öncelere uzanmaktadır. Baba Hafız Esad'ın Türkiye ile olan ilişkilerinde PKK terör örgütünü desteklemeyi bir dış politika aracı olarak yoğun bir şekilde kullanmaya başlamasıyla beraber iki ülke arasında geçmişten beri sorunlu olan ilişkilere yeni bir problem alanı daha eklenmiştir. Türkiye ile Suriye arasında geçmişten günümüze uzanan çizgide yaşanan gerilimlerin temelinde Suriye'nin Hatay üzerinde hak iddia etmesi, su paylaşımı ile ilgili sorunlar ve PKK terör örgütünün desteklenmesinin yattığı söylenebilir.

Suriye sorunu süreç içerisinde Türkiye ve Suriye arasındaki bir gerilim olmaktan çıkarak Türkiye ile ABD arasında 1947 sonrası dönemde yaşanan en kritik sorun alanı olmaya doğru bir evrim geçirdiği izlenimini vermektedir. Suriye konusunda iki ülkenin sergilediği en somut liberal yaklaşım örneğinin güvenli bölge ve özellikle ortak harekât merkezinin oluşturulmasına yönelik yapılan müzakereler ve çalışmalar olduğu söylenebilir. Bu çalışmalarla liberal anlayışın müzakere kanalı kullanılarak taraflar arasında görüş ayrılıklarının giderilmesi ve bir uzlaşı zemininin oluşturulması hedeflenmiştir.

Suriye olayında Türkiye'nin liberal değer, realist yaklaşım ikilemi bağlamında izlediği politikalara bakıldığında üç dönemden söz edilebilir. Birinci dönem 2000-2011 yılları arasında Türkiye'nin Suriye ile olan ilişkilerinde ticareti ve her iki toplumun refah ve zenginliğini öncelediği tam bir liberal anlayış dönemi olarak nitelendirilebilir. İkinci dönem 2011-2014 yıllarını kapsayan ve Türkiye ile ABD arasında ilişkilerin genel olarak olumlu bir seyir izlediği dönem. Üçüncü dönem ise 2015'te Tel Abyad'ın YPG tarafindan ele geçirilmesi ile başlayan ve ABD ile yaşanan bölgesel çıkar temelli gerilimlerin açık bir biçimde ortaya çıktığı, realist yaklaşımların egemen olduğu günümüze kadar uzanan dönem.

Suriye olayı Türk-ABD ilişkilerinde Türkiye'nin başlangıçta müzakereler ve diplomasinin kullanımı gibi liberal yaklaşımın araçları ile sonuç almaya çalıştığı bir sorun olarak ortaya çıkmıştır. Ancak gerek müzakerelerde ulaşılan sonuçlar ve gerekse ABD tarafının Münbiç mutabakatı gibi varılan uzlaşılarda bile taahhütlerinin gereklerini yerine getirmemesi üzerine Türkiye artan bir ivme ile tam bir realist yaklaşım örneğini sahaya yansıtmaya başlamıştır. Türkiye'nin bölgesel çıkarları adına gerçekleştirdiği askeri operasyonlar zorlayıcı güç unsurlarının sahada uygulanarak sonuç elde edilmesine yönelik açı örnekleri oluşturmaktadır.

\section{TÜRK-AMERIKKAN ILIŞKILLERI: SURIYYE GERILIMI}

PKK terör örgütünün Türkiye'ye karşı bir politika aracı olarak yoğun bir şekilde kullanılması Suriye siyasetinde etkin bir figür olarak 1970'li yıllardan itibaren ortaya çıkan Hafız Esad döneminde gerçekleşmiştir. H. Esad özellikle 80 ve 90'lı yıllarda PKK terör örgütüne barınma, eğitim ve topraklarını kullanarak Türkiye'ye yönelik saldırıları gerçekleştirebilmesi için gerekli alt yapıyı sağlamanın yanı sıra terör örgütün elebaşı A. Öcalan'a 1979 yılından itibaren Şam'da ikamet izni de vermiştir. Suriye üzerinden Türkiye'ye yönelik yapılan terör saldırılarında artış Türkiye'yi ciddi anlamda rahatsız etmiştir. 1998'e gelindiğinde dönemin Cumhurbaşkanı Süleyman Demirel Suriye'ye karşı mukabelede bulunabilecekleri yönünde basına beyanatlar vermiştir. Bu günlerde Türk silahlı kuvvetleri Suriye sınırına askeri yığınak yapmaya başlamıştır. 16 Eylül tarihinde dönemin Kara Kuvvetleri Komutanı Atilla Ateş Hatay'ın Reyhanlı ilçesine gitmiş burada verdiği demecinde açıkça Suriye'nin ismini telaffuz ederek eğer Suriye gerekli adımları atmazsa her türlü tedbiri alma hakları olduğu yönünde beyanda bulunmuştur. İki tarafın savaşın eşiğine geldiğini gören dönemin Mısır Devlet Başkanı Hüsnü Mübarek devreye girerek taraflar arasında arabulucu olmuştur. Türk tarafi Suriye devleti ile PKK arasındaki ilişkileri, Suriye istihbarat örgütü mensuplarının A. Öcalan'ı nasıl koruduklarını da içeren geniş kapsamlı bir 
dosyayı H. Mübarek'e vermiştir. H. Mübarek'in arabuluculuğuyla Suriye A. Öcalan'ı topraklarından çıkarmayı kabul etmiş ve 9 Ekim 1998 tarihinde A. Öcalan Atina'ya gönderilmiştir. A. Öcalan'ın sınır dışı edilmesi taraflar arasında tansiyonu düşürmüş, 20 Ekim 1998 tarihinde imzalanan Adana Mutabakatı ile ilişkilerde yeni bir döneme girilmiştir (Aljazeera, 2014).

Adana Mutabakatı beş maddeden oluşan bir antlaşmadır (Türkiye Büyük Millet Meclisi, 2011). Mutabakatın maddeleri incelendiğinde ve özüne bakıldığında Suriye hükümetinin PKK'yı terör örgütü olarak kabul ettiği, başta PKK olmak üzere terör örgütlerine destek vermeyi keseceğini taahhüt ettiği görülmektedir. Bu mutabakat aynı zamanda tarafların teröre karşı ortak iş birliği yapmalarını öngören bir anlaşmadır. İki ülke arasındaki ilişkilerin olumlu yönde gelişimine paralel olarak Adana Mutabakatı'nı 21 Aralık 2010 tarihinde imzalanan Terör ve Terör Örgütlerine Karşı Ortak İşbirliği Anlaşması izlemiştir. Bu anlaşma Adana Mutabakatına atıfta bulunarak teröre karşı mücadele ve güvenlik alanlarında daha fazla iş birliği olanaklarının yaratılmasını öngörmüştür. Bu anlaşma ile bir anlamda taraflar arasında daha yoğun bir iş birliği gerçekleştirilmesi için gerekli hukuki çerçeve oluşturulmaya çalış1lmıştır. Anlaşma dokuz bölüm ve yirmi üç maddeden oluşmaktadır. Bu Anlaşmayı Adana Mutabakatı'nın geliştirilmiş bir versiyonu olarak değerlendirmek mümkündür.

İki ülke ilişkilerinde olumlu yönde görülen gelişmeler dizisinin 2000 yılında Beşşar Esad'ın ölen babasının yerine yönetime geçmesi ile hız kazandığı söylenebilir. B. Esad'ın yönetime gelmesi ile iki ülke arasında üst düzeyde yapılan temaslarda bir artış görülmüştür. B. Esad 2004 yılında Ankara'ya bir ziyaret gerçekleştirmiştir. Yine aynı yıl Türkiye ile Suriye arasında serbest ticareti öngören bir ortaklık anlaşması imzalanmıştır. 2005 yılında dönemin Cumhurbaşkanı Ahmet Necdet Sezer Suriye'yi ziyaret etmiştir. Türkiye 2008 yılında İsrail ile Suriye arasındaki görüşmelerde arabuluculuk yapmıştır. İki ülke ilişkilerinde olumlu esen bir rüzgâr olarak nitelendirilebilecek bu eğilim 2010 yılında başlayan Arap Baharı ile tersine dönmüştür. Arap Baharı 15 Mart 2011 tarihinde Ürdün sınırındaki Dera kentinde başlayan protesto gösterileri ile Suriye'yi de etkilemeye başlamıştır. Gösteriler hızla diğer kentlere yayılmıştır. Türkiye B. Esad'a bu süreçte reformlar yapması ve gösterileri bastırmak için şiddete başvurmaması yönünde telkin ve tavsiyelerde bulunmuştur. Dişişleri Bakanı Ahmet Davutoğlu Esad'ın Türkiye'nin tavsiye ve telkinlerini dikkate almaması üzerine Ağustos ayında artık Suriye ile bu noktadan sonra yapılacak bir şey kalmadığı yönündeki görüşlerini kamuoyu ile paylaşmıştır. Başbakan Recep Tayyip Erdoğanda Eylül ayında Mısır'a gerçekleştirdiği ziyarette B. Esad'ın inanırlığını ve güvenilirliğini yitirdiğini beyan etmiştir (Aljazeera, 2014).

Suriye ile Türkiye arasındaki ilişkilerin olumsuz görünüm almaya başladığı dönem aynı zamanda Türkiye ile ABD arasında Suriye sorunun bir gündem maddesi olarak yoğun bir şekilde yerini aldığ 1 dönem olarak da görülebilir. Suriye'de rejim karşıtı ayaklanmaların başladığı ilk dönemlerde Türk ve ABD tarafının Suriye sorununa yönelik tavrının paralellik taşıdığı görülmektedir. Bunun en somut örneği ABD Dışişleri Bakanı Hillary Clinton'un öncülüğ̈̈nü yaptığı Suriye'nin Dostları Grubu'nun ikinci toplantısının Nisan 2012 tarihinde İstanbul'da yapılmasıdır. Açılış konuşmasını Başbakan Recep Tayyip Erdoğan'ın yaptığı bu toplantıda Suriye Ulusal Konseyi tüm Suriyelilerin meşru temsilcisi olarak duyurulmuştur. Bu toplantıda ayrıca B. Esad'a şiddete son vermesi için nasıl bir baskı uygulanacağ tartışılmıştır. H. Clinton'da toplantıda engellemelere rağmen Suriye'deki muhaliflere iletişim malzemesi ve tıbbi malzeme yardımı yapılacağını, B. Esad'ın halkına yönelik şiddet hareketlerinden caydırılması için bir dizi uluslararası yaptırım üzerinde yoğunlaşmak gerektiğini açıklamıştır. Toplantı ile ilgili olarak Suriye Devlet Haber Ajansı (SANA) toplantının Suriye'nin dostları tarafindan değil Suriye'ye karşı düşmanca bir komplo içersinde olan çevrelerce düzenlendiğini dile getiren yayınlar yapmıştır (Aljazeera, 2012). Türk ve ABD taraflarının Suriye probleminin çözümüne yönelik karşılıklı iş birliği ve müzakere araçlarını kullandığı diplomasi temelli anlayış ABD tarafında memnuniyet yaratmıştır. $\mathrm{H}$. Clinton 2014 yılında piyasaya çıkan Zor Seçimler isimli kitabında görevde olduğu 2008-2012 yılları arasındaki dönemde Suriye meselesinde Türkiye ve ABD'nin yaklaşımlarının uyum içinde olduğunu ve bu konuda Türkiye ile ortak bir anlayışa sahip olduklarını dile getirmiş̧tir (Clinton, 2014).

Taraflar arasında Suriye sorununa yönelik kısmen iş birliği yapılan belki de son olay olarak Ayn el Arab (Kobani) hadisesi görülebilir. Bu hadise aynı zamanda Suriye'nin kuzeyindeki gelişmelerde dönüm noktası sayılan olaylardan biri olarak değerlendirilebilir. 2014 yılında Ayn el Arab'da DAEŞ ile çatışan YPG'ye B. Obama yönetimi ilk kez havadan silah ve malzeme yardımında bulunmuştur. ABD yönetimi bu yardımları C130 kargo uçaklarını kullanarak gerçekleştirmiştir. İlk etapta yapılan yardım 24 ton silah ve mühimmat ile 10 ton tıbbi malzemeden oluşmuştur. Türk hükümeti de bu olayda Irak kuzeyinden gelecek Kürt milislere Ayn El Arab'a geçmeleri ve destek vermeleri için sınır kapılarını açacağını deklere etmiştir. ABD Dışışleri Bakanı John Kerry ABD'nin yaptığı yardımı meşrulaştırmak için "DAEŞ ile mücadele eden bir gruba sırtımızı dönmek ahlaki olarak çok zor" ifadelerini kullanmıştır. Türk Dışişleri Bakanı Mevlüt Çavuşoğlu da Ayn El Arab'a yardım operasyonunu DAEŞ'e karşı yapılan geniş kapsamlı mücadelenin bölgesel bir parçası olduğu yönünde 
değerlendirmelerde bulunmuştur (The Guardian, 2014). DAEŞ ile olan mücadelede Türkiye ve ABD'nin eğitdonat programı çerçevesinde silahlı eğitim verdiği ÖSO (Özgür Suriye Ordusu) unsurları 2015 yılında Suriye'de DAEŞ ile olan mücadele kapsamında çatışmalara başlamışlardır. Ancak ABD'li yöneticiler ÖSO unsurlarının istenen başarıyı gösteremediğini düşünüyorlardı. ABD'nin bölgede ortak hareket edebileceği yerel unsur arayışları kapsamında YPG'ye daha fazla yönelmesi Türkiye'nin rahatsızlıklarını artırmıştır. ABD'nin YPG'yi ön plana çıkarması Türk-Amerikan ilişkilerinde çatlaklar yaratan dönüm noktalarından biri olmuştur (DeutscheWelle, 2018). Türkiye özellikle Suriye'de ABD'nin PYD/YPG unsurlarını desteklemesinden rahatsız olmakta ve bunu bölgesel çıkarlarına aykırı görmektedir. Suriye'nin yaklaşık dörtte birlik kısmını kontrol eden Demokratik Birlik Partisi (PYD) ve onun silahlı unsuru Halk Koruma Milisleri olarak adlandırılan (YPG) Suriye'de iç savaşın başlamasıyla ortaya çıkmıştır. Suriye Savaşı'nın başlaması ile beraber rejime bağlı güçler 2012 yılının Temmuz ayında Suriye'nin diğer bölgelerindeki ayaklanmalara yoğunlaşmak için çekilirken kuzeydeki PYD/YPG unsurları hiçbir çatışma yaşamadan Suriye'nin kuzeyindeki bölgelerin kontrolünü ele geçirmişlerdir. YPG'nin etkisi ABD önderliğindeki DAEŞ'e karş1 olan koalisyona katılmasıyla genişlemiştir (Crisis Group, 2013).

Gerek M. Çavuşoğlu'nun söylemlerinin gerekse Türk hükümetinin tavrının 2015 yılında değiştiği görülmektedir. 2015 yılı Türkiye'nin Suriye politikasında değişmelerin olduğu yıl olmuştur. 2015 yılının Haziran ayında YPG, ağırlıklı nüfusu Araplardan oluşan Tel Abyad kentini ele geçirdi. YPG'nin bu hamlesinin amac1 YPG tarafindan Cezire kantonu olarak adlandırılan bölgenin Ayn el Arab ile birleştirilmesi ve kantonlar arasında toprak bütünlüğünü sağlamaktır. YPG'nin bu hamlesi Türkiye'yi harekete geçirmiştir. 29 Haziran'daki Milli Güvenlik Kurulu toplantısında Türkiye, Fırat'ın batısına yönelik herhangi bir girişimi kırmızı çizgisi olarak deklere etmiştir (TRT World, 2016).

Türkiye'nin askerî operasyonlarını tetikleyen olaylardan birisi YPG'nin 2016 tarihinde Münbiç’i ele geçirmesidir. YPG'nin Münbiç'i ele geçirmesi ve buradaki varlı̆̆ 1 Türkiye'yi rahatsız etmiştir. Türkiye'nin uzun süren diplomatik çabaları ve ABD'nin isteksiz yaklaşımına rağmen taraflar arasında 2018 yılının Haziran ayında Münbiç Mutabakatı olarak adlandırılan uzlaşıya varılmıştır. Türk tarafı bu anlaşmanın gecikmesi ile ilgili olarak Amerikan tarafının isteksizliğinden doğan rahatsızlığını pek çok kez dile getirmiştir (Szuba, 2019). Münbiç Mutabakatı genel olarak üç aşamalı denilebilecek bir süreci içeriyordu. İlk aşamada YPG unsurları Münbiç'i terk edecek ve burada oluşturdukları yapılar ortadan kaldırılarak Fırat'ın doğusuna çekilmeleri sağlanacak, ikinci aşamada Türk ve Amerikan askerî unsurları denetimi ele alacaklar, üçüncü aşamada ise YPG'nin bölgede oluşturduğu yönetimsel ve idari yapılar lağvedilerek bölgenin ağılıklı unsuru olan Araplardan oluşacak yeni yönetimsel yapılar kurulacaktı. Münbiç Mutabakatı'na rağmen anlaşılan konularla ilgili kayda değer bir gelişmenin ortaya çıkmaması üzerine Türk tarafı bunu bir oyalama taktiği olarak değerlendirmiş ve askerî operasyon seçeneğini sık sık dillendirmeye başlamıştır. Münbiç konusunda kayda değer bir gelişme olmaması üzerine bu süreçte D.Trump yaklaşık $30 \mathrm{~km}$ derinliğinde bir güvenli bölge önerisini ortaya atmıştır. Ancak güvenli bölge konusunda Türkiye'nin ve Amerika'nın bakış açılarının farklı olduğu görülmektedir.

Türk tarafı kendi hâkimiyetinde terör unsurlarından tamamen arındırılmış Irak sınırına kadar olan bir bölgeyi düşünürken $\mathrm{ABD}$ tarafı bu güvenli bölgeyi Türk ordusu ile YPG arasında ortaya çıkabilecek çatışmaları engelleyecek ve Türkiye'nin güvenlik konusundaki endişelerini giderecek tampon bir bölge olarak görmüştür. Amerikan tarafi Türk Ordusu'nun güvenli bölgeye girmesini istememektedir. Amerikalılar bu güvenli bölgenin askerî kontrolünün İngiltere ve Fransa gibi uluslararası güçlerden oluşan bir yapı tarafından gerçekleştirilmesini istemektedirler. Mahalli düzeyde güvenliğin ise Suriye Demokratik Güçleri'nin Arap unsurları ve Irak KDP yönetimi tarafından oluşturulacak unsurlarla sağlanmasını öngörmektedirler. Türkiye, Suriye Demokratik Güçleri ve Peşmerge unsurlarının mahalli güvenlik için birlikte çalışmasına üzerinde tartışılabilir bir konu gibi bakarken bölgenin uluslararası güçlerin askeri kontrolünde olması önerisine karşı sert tavır göstermektedir. Türkiye böyle bir yapının YPG’ye uluslararası koruma ve meşruiyet sağlayacağını düşünmektedir. Bu görüş ayrılıkları ortada dururken yapılacak müzakerelerden anlamlı bir sonuç çıkması zor görünmektedir. Bu süreçte Türkiye Münbiç ve Fırat'ın doğusu konusunda Rusya ile temasta bulunmuştur (Oytun, 2019). Münbiç konusunda Türkiye'nin 1srarcı olmasının nedeni olarak Fırat'ın batısında YPG kontrolündeki oluşturulacak kalıcı yapıların ortaya çıkması olasılı̆̆ından duyulan rahatsızlık olduğu düşünülebilir. ABD'nin Irak kuzeyi ve YPG'ye yönelik olarak izlediği politikaların hatalı olduğuna yönelik yaklaşım ortaya koyan ABD kökenli kurumlar da mevcuttur. ABD Hudson Enstitüsü uzmanlarından Mike Doran Suriye'deki durumun değerlendirildiği bir panelde yaptığı konuşmada ABD'nin Suriye'nin kuzeyine ilişkin politikasını stratejik olarak hatalı bulduğunu ifade etmiştir. ABD, YPG'yi desteklediğini ileri sürerken aslında PKK'y1 desteklemiştir. Bu terör unsurlarının ilerleyen dönemlerde Rusya ve B. Esad tarafından kullanılması söz konusu olabilecektir (YouTube, 2019). M. Doran'ın mülakatı başta Dışişleri Bakanı Mevlüt Çavuşoğlu olmak üzere pek 
çok devlet yöneticisi tarafından paylaşılmıştır. M. Doran'ın düşünceleri Türkiye'nin argümanları ile örtüşmektedir.

Tarafların çıkarlarının çatıştığı bu süreçte Amerikan tarafı Türkiye'yi radikal grupları desteklemekle itham etmiştir. Türkiye ABD'nin yönelttiği radikal grupları destekleme iddiasını hiçbir zaman kabul etmemiştir. İki taraf zaman zaman birbirlerini bölgedeki istikrarı bozucu aktörler olarak tanımlamışlardır. Taraflar arasında anlaşmazlık güvenli bölge oluşturulması konusunda da devam etmiştir. Türkiye ulusal güvenliği için $32 \mathrm{~km}$ derinliğinde Irak sınırına kadar uzanan bölgede tam bir kontrol talep ederken Amerikan tarafının önerisi ise 5-14 km derinliğinde bir güvenli bölge olmuştur (Stein, 2019).

Eski Alman Dışişleri Bakanı Sigmar Gabriel Suriye iç savaşının başlamasından sonra Türkiye'nin Cumhurbaşkanı Tayyip Erdoğan nezdinde uçuşa yasak bir alan ve güvenli bölge oluşturulması teklifinin kendilerine sunulduğunu verdiği demeçlerle dile getirmiştir. Türkiye'nin güvenli bölge önerisinin kabul edilmemesi daha sonra Avrupa siyasetinde yapılmış bir hata olarak değerlendirilmiştir (NTV, 2019).

Suriye'deki karmaşa Türkiye'nin ulusal güvenlik kaygılarına yönelik davranışlarını da tetiklemiştir. Türkiye ulusal güvenlik hassasiyetleri ve güvenli bölge oluşturulması kapsamında Suriye'nin Kuzeyine yönelik bir dizi askerî harekât düzenlemiştir. Bu harekâtlardan birincisi 24 Ağustos 2016 tarihi ile 27 Mart 2017 tarihleri arasında gerçekleşen Fırat Kalkanı Harekâtı'dır. İkincisi 20 Ocak 2018 tarihinde başlayan Zeytin Dalı Harekâtı'dır (NTV, 2019). Türkiye'nin 2016 yılında gerçekleştirdiği Cerablus bölgesinin merkezini oluşturduğu harekât hem terör örgütü PKK/YPG unsurlarına hem de DAEŞ unsurlarına yönelik olarak gerçekleştirilmiştir. Türkiye'nin özellikle sahte kimliklerle Türkiye'ye geçen ve toplumda infial yaratan saldırılar gerçekleştiren DAEŞ'e karşı böyle bir operasyon gerçekleştirmek zorunluluğu ortaya çıkmıştır. Bu harekât Firat Kalkanı olarak isimlendirilmiştir. Takip eden süreçte yine 2018 yılında gerçekleştirilen Zeytin Dalı Harekâtı ise ağırlık merkezini Afrin Bölgesi'nin oluşturduğu bir operasyondur. Bu operasyonun ana hedefi Türkiye'nin hemen sinır bölgesindeki PKK/YPG oluşumlarını ve üslenmesini dağıtmak şeklinde belirlenmiştir. Bu harekât Afrin operasyonu olarak da isimlendirilmektedir (Demir, 2019:239). Türkiye'nin BM Antlaşmasının 51. maddesine göre Suriye'nin Kuzeyine düzenlediği 3. harekât Barış Pınarı Harekâtı'dır. BM Antlaşmasının 51. maddesi BM üyelerinden herhangi birinin silahlı saldırıya uğraması durumunda BM'nin barış ve güvenliğin korunmasına yönelik tedbirleri almasını beklemeden meşru savunma hakkını kullanmasına olanak tanımaktadır (Anadolu Ajans1, 2018).

Türkiye'nin Suriye konusundaki taleplerinden biri olan Güvenli Bölge'nin oluşturulmasına ilişkin ilk adımlar 5 Ağustos 2019 tarihinde atılmıştır. Güvenli Bölge'nin oluşumu ve koordinasyonuna ilişkin ilk uzlaşıya Türk ve ABD tarafları arasında 7 Ağustos 2019 tarihinde ulaşılmıştır. Bu uzlaşıya göre oluşturulan Birleşik Müşterek Harekât Merkezi Şanlıurfa'nın Akçakale ilçesinde 12 Ağustos'ta faaliyetlerine başlamıştır. Türk ve ABD askerî unsurları Fırat'ın doğusunda güvenli bölge oluşturulması faaliyetleri kapsamında ilk askerî devriyelerinin 8 Eylül 2019 tarihinde Akçakale ilçesinin karşısındaki bölgeye denk gelen Suriye topraklarında icra etmişlerdir (T.C. Milli Savunma Bakanlığı, 2019). Ortak devriye faaliyetlerinin bölgenin güvenli hale getirilmesi konusunda istenilen sonuçların elde edilmesi için yetersiz kaldığını düşünen Türk Tarafı 9 Ekim 2019 tarihinde Barış Pınarı Harekâtı'nı başlatmıştır. Harekâtın amaçlarına ilişkin olarak Cumhurbaşkanı Recep Tayyip Erdoğan sosyal medya hesabı üzerinden kamuoyunu bilgilendirmeye yönelik paylaşımlarda bulunmuştur. 9 Ekim tarihinde başlayan harekâtın temelde üç amacının olduğu ifade edilmiştir. Harekâtın birinci amacı bölgenin PKK/YPG ve DAEŞ gibi terör örgütlerinden temizlenmesi, ikinci amac1 Suriye'nin kuzeyinde Türkiye'nin tam hâkimiyet ve kontrolünün olduğu bir Güvenli Bölge oluşturulması, üçüncüsü Suriyeli sığınmacıların ülkelerine dönüşünün sağlanmasıdır (Erdoğan, 2019). Barış Pınarı Harekâtı'nın başlamasından sonra ABD Başkan Yardımcısı Mike Pence başkanlığında ABD'li bir heyet Türkiye'ye gelerek 17 Ekim tarihinde Cumhurbaşkanı Recep Tayyip Erdoğan başkanlığındaki Türk heyeti ile Suriye'nin kuzeyine ilişkin müzakerelerde bulunmuştur. Dört saatten uzun süren müzakerelerin ardından taraflar 13 maddelik bir mutabakat metni üzerinde anlaştıklarını duyurmuştur. Bu mutabakatla Türkiye'nin operasyonu durdurması ve YPG unsurlarının 120 saat içersinde güvenli bölge olarak belirtilen 32 kilometrelik alanın dışına çıkmaları kayıt altına alınmıştır. Mutabakatın 12.maddesi D. Trump'ın Başkanlık Kararnamesi ile açıkladığı Türkiye'ye yönelik yaptırımların uygulanmayacağını öngörmüş̧ür (BBC, 2019). 12. madde ile ABD tarafi en azından yakın gelecekte Türkiye'ye kapsamlı birtakım yaptırımlar uygulanmayacağının güvencesini vermiştir.

ABD'nin YPG'yi neden desteklediği ve geleceğe yönelik olarak bu olayın daha ne kadar süreceği uzmanlar arasında tartışma konusu olarak varlığını devam ettirmektedir. H. Bağcı Suriye'nin kuzeyinde desteklenen gruplarla İsrail'in güvenliği arasında ilişki olduğu tezini ileri sürmektedir. ABD dış politikasının temel ilke ve unsurlarından biri İsrail'in güvenliğinin sağlanmasıdır. ABD'nin hem kendisi hem İsrail 1979 yılından beri İran ile düşmanca bir ilişki içersindedir. İran ile İsrail arasında vuku bulacak çatışmalar için bir tampon oluşturmak 
ve özellikle İran'ın bölgedeki etkisini azaltmak için Suriye'nin kuzeyindeki YPG gibi gruplar ABD için düşük maliyetli bir askerî kaynak teşkil etmektedirler (YouTube, 2019). İsrail Lobisi'nin ABD'deki gücü ve ABD dış politikasını belirlemedeki etkisi dikkate alındığında İsrail'in güvenliğini ana amaç olarak belirleyen ve bunun için YPG gibi grupları her düzeyde destekleyen bu politikaların daha uzun süre devam edeceği anlaşılmaktadır.

\section{ARASTTIRMANIN METEDOLOJISI VE UYGULAMASI}

\subsection{Araştırmanın Konusu, Amacı ve Yöntemi}

$\mathrm{Bu}$ araştırmanın konusu Türk-Amerikan ilişkilerinde 2002 sonrası dönemde yaşanan gerilimler zincirinin halkalarından birisi olarak nitelendirilebilecek Suriye geriliminde tarafların sorunun çözümü için ne tür yaklaşımlar sergilediklerini incelemektir. Bu amaçla doküman incelemesi ve konunun uzmanlarıyla mülakatlar yapılarak elde edilen bulgular çerçevesinde konu ile ilgili tartışmalara katkı sağlanmaya çalışılmıştır. Bu araştırmanın amac1, özellikle 2002-2020 döneminde Türkiye ve ABD arasında küresel gelişmelerden kaynaklı farklılaşan ulusal güvenlik kaygıları ve çıkarlarının neden olduğu Suriye Gerilimi konusunda sorunun çözümü için tarafların ne tür yaklaşımlar tercih ettiklerini incelemektir. Bu çerçevede, nitel araştırma desenlerinden vaka çalışması türlerinden açıklayıcı/tanımlayıcı durum yöntemi kullanılacaktır. Bu yöntemde veri toplama amacı ile kullanılan araçlardan olan mülakat yöntemi ve doküman incelemesi ile veri toplanmıştır.

\subsection{Araştırmanın Veri Toplama Aracı}

Bu veriler için, Türk-ABD ilişkileri alanında uzman olan Sabah Gazetesi Washington eski temsilcisi Ragıp Soylu, Prof. Dr. Füsun Türkmen, Emekli Büyükelçi Patrick N. Theros, ABD’li emekli ulusal güvenlik uzmanı Albay William Downey, Prof. Dr. Kemal Kirişci, Prof. Dr. Birol Yeşilada, Prof. Dr. İlter Turan ile açık uçlu sorulara dayalı mülakat gerçekleştirilmiştir. Bununla birlikte, literatürdeki çalışmalar ile kamu erişimine açık olan bilgi/belge ve dokümanlardan istifade edilmiştir. Bu kapsamda her iki ülke yöneticilerinin sosyal medya hesapları üzerinden yaptıkları paylaşımlar ve bahse konu vakayla ilgili ciddiyeti ve saygınlığıyla bilinen yayın organlarında yer alan haberlerden yararlanılmıştır. Verilerin analizi ve yorumlanmasında betimsel-yorumlayıcı analiz tekniği kullanılmıştır.

\subsection{Araştırmanın Bulguları}

Suriye gerilimine ilişkin olarak uzmanlar tarafından şu görüşler ileri sürülmüştür;

- Ragıp SOYLU (Mülakat, 27 Aralık 2019): “Amerikan tarafi B. Esad ile mücadelede çekimser davranmasının nedenini Türk tarafina söylemedi ama neden Iran anlaşmasıydı. Obama İran'la anlaşmak istiyordu. Iran Suriye'de aktif bir şekilde Esad'ın yanında muhalefete karşı savaş içindeydi. Amerika Suriye'de Iran'a karşı hareket ederken Iran'la nükleer anlaşma imzalayamazd. Ana neden bu yani. Türkiye'yi ikna etmeye çalıştılar, bu amaçla Eğit-Donat yapalım DAEŞ'le savaşalım gibi teklifleri sundular ancak bunlardan bir sonuç alamadılar. Sonra 2014'te malum [Ayn el Arab] olayı gerçekleşti. Amerikalıların ısrarlarıyla Peşmerge'nin bir kısmının Suriye'ye geçmesine izin verildi. Sonraki süreçte ise PYD lideri Salih Müslim Ankara'ya geldi. Türk yetkililer orta yolu bulmaya çalıştılar. Türk hükümeti yetkilileri PYD'den Suriye muhalefeti ile beraber hareket etmesini istediler ama bu kabul görmedi. Orada istenilen şeyler alınamad. Ama tabi ABD artık YPG ile çalışmaya başlayınca PKK da Barış Sürecini umursamamaya karar verdi. 2015 yllında PKK'nın polis ve askerleri şehit etmesinin sonucunda Barış Süreci bitti. Türkiye, PKK ile savaşmaya başlayınca endirekt olarak YPG ile de savaşmaya başlamış oldu."

- Prof. Dr. Füsun TÜRKMEN (Mülakat, 1 Ocak 2020): "IŞİD faktörünün ortaya çıkmasıyla Batının Suriye konusundaki tavrı değişti. İki kötü arasında daha az kötüyü seçmek yoluna gitti. Yani önceliği DAEŞ ile mücadele haline geldi ve Esad'ın devrilmesi önceliğinden yavaş yavaş vazgeçildi. Bu kadar basit, böyle bir yaklaşım değişikliği oldu. Amerikan tarafinın tavrına baktığımızda mesela hatırlarsanız Obama "Kırmızlçizgimiz kimyasal silah kullanılması." dedi. 2013'te pembe oldu o çizgi. Kimyasal silah kullanıld, yine de müdahale etmedi. 2012 Haziranı'na kadar Suriye'de bir şey yapılabilseydi Suriye'nin bu korkunç iç savaşa sürüklenip bütün etrafinın da tarumar olmasına mâni olunabilirdi. Çünkü daha Rusya sahada yoktu, Hizbullah bu kadar aktif değildi. Iran Suriye ordusunu böyle çevrelemiyordu. IŞID gibi aşırı terör örgütleri ortaya çıkmamıştı. Bu bir insancıl müdahale yoluyla Batı tarafindan Arap 
Baharı çerçevesinde önlenebilirdi. Batı oradan uzak durmayı seçti. Çünkü Irak Savaşı'nın büyük bir hata olduğu düşünüldügünden ikinci bir müdahaleyi göze alamadılar. Sonuçta IŞìD ortaya çıktı, Rusya sahaya indi ve yalnız Amerika değil, Avrupa'da bertaraf oldu."

- Emekli Büyükelçi Patrick N. THEROS (Mülakat, 19 Haziran 2020): "Suriye meselesi Türkiye ile $A B D$ askeri ve istihbarat servisleri arasında derin bir çatlak yarattı. Oluşan bu çatlağın ABD Dışişleri Bakanlı̆̆ üzerindeki olumsuz etkisinin daha az olduğu söylenebilir. D. Trump Türkiye'nin eylemlerinden memnun görünüyor ancak yansımaların her zaman anlamıyor."

- ABD'li emekli ulusal güvenlik uzmanı Albay William DOWNEY (Mülakat, 10 Temmuz 2020): "Suriye meselesine gelince, Türkiye PKK ve SDF terörizmine karşı mücadele edeceğini önceden deklere etti. Türkiye bu amacını gerçekleştirmek için Suriye'ye askerî müdahalede bulundu. Askeri müdahalelerde temel hedefin Suriye Kürtleri ile Türk sinırı arasında bir tampon bölge oluşturmak olduğu söylenebilir. Amerika Birleşik Devletleri Suriye’deki askerî varlığının yetersiz olduğunu hissettiğinden Türk kuvvetlerinin ilerlediği alanlardan çekildi. Öyle görünüyor ki, Suriye'de bu olanların bir zamanlar çok yakın müttefik olan iki ülkenin ilişkileri üzerinde ürpertici etkisi oldu. "

- Prof. Dr. Kemal KİRİșCi (Mülakat, 22 Temmuz 2020): “Suriye'deki askerî kayıplar hep Suriye hükümetine ve ordusuna faturalanıyor. Ancak Türkiye'nin Suriye’deki askeri kayıplarının arkasında Rusya'nın olabileceğini çok kişi açık açık söylüyor."

- Prof. Dr. Birol YEŞiLADA (Mülakat, 25 Mayıs 2020): "Amerikalılar Suriye'den çekildiklerinde Rusya kırmızıçizgiyi belirlemeye başladı. Amerikalılar Suriye'de aktif olarak kalmadılar, Kürtlere yardım ederek kaldılar, kendi güçlerini çektiler. Bu durum karşısında Ruslara yaklaşıldı ancak Ruslarla problemler yaşandı. Sonunda orada Türkiye, Rusya ile karşı karşıya kalıyor. Benim izlediğim böyle bir durum var. Rusya'ya yaklaşılmasını ben çok riskli buluyorum. Üç yüz senedir tek bir hedefi vardır Rusların o da Boğazları ele geçirmek. Şunu unutmayalım ki 17 savaş yapılmış Ruslarla tek dostluk süreci Kurtuluş Savaşı ve hemen sonrasıdır. II. Dünya Savaşı'nın bitimiyle beraber Ruslar hemen Türkiye'den büyük taleplerde bulunmaya başladılar. Rusların bu taleplerini Truman Doktrini engelledi. Ruslar hâlâ bu süreci unutmuş değiller. Ruslar Türkiye'yi Batı'dan uzaklaştırıp NATO'yu içerden vurmaya çalışıorlar. Batı ittifakı içersinde iki önemli ordu var birisi ABD ordusu diğeri ise Türk ordusu, İngiliz ordusunun durumu ise içler acısı. Diğer ülkelerin ise kayda değer bir askeri güçleri yok. Ruslar tarafindan Türkiye 'nin Batı ittifakının dışına çekilmek istenmesinin ana nedenlerinden biri de bu."

- Prof. Dr. İlter TURAN (Mülakat, 8 Aralık 2019): "Suriye'de Amerika'ya baktığımız zaman, Rusya ile Amerika'nın çıkarlarının iç içe geçtiğini görüyoruz. Çünkü Rusya da Amerika da Irran'ın nüfuzunun batıya doğru uzanmasını istemiyor. Rusya ve Amerika bir anlamda zımni bir iş bölümü yaparak Suriye'de DAEŞ'e karşı mücadele yürütüyorlar. Amerika kendi asker sayısını arttırmakta isteksiz olduğu için, bu iş için vekâleten YPG'yi buldu, onu kullaniyor. Kendileri bunun bir taktik iş birliği olduğunu ifade ettiler. Belki bir ölçüde öyledir, fakat bunun ötesinde Türkiye'yi giderek daha az güvenilir bir ortak olarak gördükleri için, belki de bu bölgede başka müttefikler oluşturmaya çalışlyorlar. Ayrıca YPG'nin Kuzey Suriye'de güçlenmesi Suriye'nin İsrail üzerindeki baskısının ve tehdidinin de zayıflamasını sağlayacaktır. Ileride burada bağımsız bir ülke oluşacak olursa çevresindeki bütün ülkelerle kavgalı olacağ için Amerika'nın desteğine fazlasıyla ihtiyaç duyacaktır. Dolayısıyla Amerika'da burada istediği gibi at koşturabilecektir. Esad Amerika'nın oradan çıkmasını sağlamak için bir miktar muhtemelen o bölgede Kürtlere siyasi bir serbesti tanıyan bir yapılaşma öngörecektir, böyle bir çözüme doğru gidilecektir. Şu anda kimin ne kadar güçlü olduğu ve daha neler yapabileceği belirsiz olduğu için mücadele devam etmekte, henüz çözüm aşamasinda değiliz."

Suriye gerilimi konusunda uzmanlar tarafından ileri sürülen görüşlerle ilgili olarak şunları ifade etmek mümkündür; Ragıp Soylu Türkiye'nin Esad'ın gitmesi hedefine yoğunlaştığını ancak Amerikan tarafının İran ile nükleer anlaşma yapmak istemesi nedeniyle bu konuda çekimser davrandığını ileri sürmektedir. Soylu, ABD'nin Suriye'de bir anlamda İran ile savaşırken nükleer bir anlaşma imzalamasının mümkün olamayacağına vurgu yapmaktadır. Soylu'nun ikinci argümanı ise İşiD'e karşı mücadelede ABD'nin YPG'ye ağırlık vermesinin de taraflar arasında görüş ayrılıklarını derinleştirdiği şeklindedir. Soylu, 2015 tarihine kadar PYD'li Salih Müslim'in Ankara'ya ziyaretler gerçekleştirdiğini, ancak Müslim'in Türk hükümetinin Suriye'deki diger muhalif gruplarla beraber hareket etmesi yönündeki önerilerini kabul etmediğini ifade eder. Soylu'nun dikkat çektiği diger bir nokta da 2015 sonrası dönemde PKK terör örgütü eylemleri nedeniyle Türk Hükümetinin PKK'ya karşı güvenlik operasyonlarını tekrar yoğun bir şekilde yürütmeye başlaması ile endirekt olarak YPG ile de çatışmaya başladığı hususudur. 
Füsun Türkmen IŞiD'in ortaya çıkışıyla Batı'nın Suriye'ye yönlik tavrının değiştiğine vurgu yapmıştır. Türkmen, Batı'nın tavrının IŞ̧iD'in ortaya çıkmasıyla Esad ile mücadele yerine Iş̧iD ile mücadeleye öncelik verme şeklinde bir değişime uğradığını ileri sürer. Amerika'nın da Suriye meselesinde net bir tavır ortaya koyamadığını ve bunun Suriye meselesini çözümü daha zor bir problem haline getirdiğini dillendirir. Türkmen Batı'nın çekingen davranmasının temelinde Irak Savaşı'nın bir hata olarak görülmesinin yattığını düşünmektedir. Türkmen, Rusya'nın sahaya inmesiyle beraber yalnızca ABD’nin değil Avrupa ülkelerinin de Suriye'de etkinliklerini kaybettikleri kanısındadır. Türkmen, Batı'nın karasızlığının yalnızca Rusya için değil aynı zamanda İran ve onunla ilişkili Hizbullah gibi gruplar için de hareket alanları yarattığı savını ileri sürmektedir.

Suriye sorununun Türk-Amerikan ilişkilerinde yaratığı etkiye ilişkin olarak Emekli Büyükelçi Patrick N. Theros bu problemin iki ülke askeri kesimleri arasında bir çatlak yarattığını, ancak iki ülke Dışişleri bakanlıkları düzeyinde uzaklaşmanın bu ölçüde büyük olmadığına vurğu yapmaktadır. Downey ise Türkiye ve ABD’nin bir zamanlar iki yakın müteffik ülke olduklarını, ancak Suriye meselesi nedeniyle oluşan uzaklaşmanın tüyler ürpertici olduğu argümanını dillendirmektedir.

Kemal Kirişci Türkiye'nin Suriye'deki askerî kayıplarının arkasında Rusya'nın olabilecegi argümanını pek çok kişinin dillendirdiğini ifade etmektedir. Birol Yeşilada da Rusya'ya güvenmenin büyük riskler taşıdığını ve Suriye savaşına müdahil olmasıyla beraber Rusya'nın sahaya hâkim olduğunu ABD'nin ise Suriye'de etkinliğini yitirdiğini ve kalıcı olmayacağı düşüncesini dile getirmektedir. 2011 yılından beri devam eden ve Türkiye'nin bölgesel çıkarları ile ulusal güvenliği açısından bir problem teşkil eden Suriye meselesinin geleceğine ilişkin olarak İlter Turan ABD'nin pozisyonunun anlaşılabilmesi için ABD-Rusya ikilisinden Rusya'nın oynadığı role dikkat çekmektedir. Turan, Suriye'de ABD ve Rusya'nın zımni bir iş birliği içinde olduklarını, Suriye'de ABD'nin kendi askerî unsurlarını kullanmak istemediğini bu nedenle vekâleten YPG'yi bulduğunu ve onu kullandığını ifade etmektedir. Turan, YPG'nin Suriye'nin kuzeyinde güçlenmesinin Suriye'nin İsrail üzerindeki baskısını azaltacağı argümanını da dillendirmektedir.

\section{SONUÇ VE ÖNERILER}

Konuya ilişkin dış politika analizi çerçevesinde Suriye gerilimine ilişkin olarak şu görüşleri ifade etmek mümkündür;

- Lider Faktörü: Obama'nın Suriye Savaşı konusunda net bir tavır takınamaması ve kararsızlığı onun sorumluluk almaktan çekinen bir lider olduğunu düşündürtmektedir. Obama'nın diplomatik pasifizm ve mevcut durumu korumaya yönelik bu tavrının gerek mülteci akımı gerekse zorunlu olarak gerçekleştirilen güvenlik operasyonları nedeniyle Türkiye'ye çok pahalıya mal olduğu ifade edilebilir.

- Türkiye - Rusya İlişkileri: Rusya'nın 2015 tarihinde Suriye savaşına müdahil olması ile beraber Türkiye sahada ABD'yi dengeleyecek başka bir aktörü kullanma olanağına kavuşmuştur. Rusya da Türkiye'nin YPG dolayısıyla ABD ile yaşadığı gerilimleri dış politikada bir firsata dönüştürerek Türkiye'yi kendi safına çekecek manevralara girişmiştir. Rusya'nın da YPG kartını kullandığını bu bağlamda ifade etmek gerekir. Türkiye'nin “Büyük Strateji” yaklaşımı çerçevesinde Rusya'yı denklemde önemli bir aktör olarak görme yaklaşımı Rusya'nın buna gereken karşılığı verememesi sonucunda akamete uğramıştır. Rusya'nın büyük resmi okuyamaması ve İdlib'de 36 Türk askerinin şehid edilmesi ile sonuçlana hadiseler Rus dış politika tarihinde son dönemde yapılmış en büyük hata olarak görülebilir. Bu olayın Türkiye bakımından sonucu Rusya'ya güvenerek diş politika kurgusu yapmak konusunda çok temkinli davranılması gerektiginin bir kez daha görülmesidir.

- Türkiye - İsrail İlişkileri: İsrail özellikle Türkiye ile ilişkilerinin iyi oldugu 1996-1998 tarihi gibi dönemlerde Suriye'nin kendisine yönelik baskısını Suriye'nin hemen ötesindeki Türkiye aracılıgıyla dengeleme yolunu seçmiştir. Ancak Türkiye ile bozulan ilişkiler böyle bir yaklaşımın devam ettirilmesine imkân vermemektedir. Bu şartlar altında İsrail'in Suriye üzerinde baskı oluşturmak için ABD kanalıyla YPG gibi terör örgütlerini kullanmaya yöneldigi ifade edilebilir. ABD’nin Ortadoğu politikalarının şekillenmesinde İsrail etkisi dikkate alındığında bu durum daha net bir şekilde görülmektedir.

- Kurumlar ve İç Siyasi Süreçlerin Etkisi: Türk güvenlik bürokrasisi ve elitlerinin özellikle 2015 tarihinde YPG'nin Tel-Abyad'ı ele geçirmesi ile Suriye'nin kuzeyinde yaşananların Türkiye'nin ulusal güvenligi bakımından rahatsızlı verici boyuta ulaştığını düşündükleri görülmektedir. Bu yaklaşımın izlerini 2015 tarihinden itibaren MGK toplantıları sonrasında basına yapılan açıklamalarda da görmek mümkündür. 
ABD yönetimi ve Pentagon ise PKK'yı bir terör örgütü olarak tanımlamasına ragmen PYD/YPG'yi terör örgütü olarak tanımlamamakta Suriye'de birlikte hareket ettiği müttefikleri olarak görmektedir. Taraflar arasında Suriye iç savaşında kullanılacak araç ve gerçekleştirilmesi düşünülen amaç konusunda görüş ayrılıklarının devam ettiği görülmektedir. Türkiye gibi kritik önemdeki bir ülkenin rahatsızlıkların ABD yönetiminde konuya ilişkin çözüm arayışlarını etkiledigi ifade edilebilir. ABD'nin yeni Genelkurmay başkanı Mark Milley'in " $A B D$ terör örgütleri ile çalışmak yerine müttefiki olan devletlerle çalışmayı tercih etmelidir", şeklindeki sözleri konuya ilişkin olumlu bir yaklaşım olarak görülebilir.

İç politik süreçler bağlamında incelenebilecek diğer bir husus da medya'nın rolüdür. ABD medyası Türkiye'nin güvenlik gerekçeleri ile Suriye'de gerçekleştirmiş olduğu operasyonları insan hakları ihlali olarak ABD ve Dünya kamuoyuna sunmaktadır. Medya'nın Türkiye aleyhtarı bu tavrının Amerikan politika yapıcıları üzerinde etkisi olduğu düşünülebilir. Bu yaklaşım Türk tarafında da rahatsızlığa neden olarak iki ülke ilişkileri üzerinde olumsuz etki yapmaktadır.

Uluslararası Koşullar: Suriye'nin Dera kentinde başlayan ve Arap Baharı dalgasının bir uzantısı olarak değerlendirilebilecek Suriye iç Savaşının başlaması ile beraber ABD ve Avrupa ülkelerinin tavrı bir diktatör olarak nitelendirdikleri Esad'ın görevi bırakması şeklinde olmuştur. O zamana kadar Suriye ile gayet olumlu ilişkiler içerisinde olan Türkiye'de bir anlamda ABD ve Batı dünyası ile paralel bir tavır takınmak durumunda kalmıştır.

Ancak $A B D$ ve Avrupa ülkelerinin Suriye meselesinin şekillenmesine etki etme konusunda gecikmeleri Rusya'nın olaya müdahil olması, İran'ın sahaya inmesi ve İşiD faktörünün ortaya çıkmasıyla beraber Batı dünyası Esad'ın gitmesi önceliğinden vazgeçmiştir. ABD Obama döneminde Suriye'de kimyasal silah kullanılmasına rağmen olaya müdahil olmamıştır. Mevcut ABD dışişleri bakanı Anthony Blinken geçmiş dönemde Hudson enstitüsünde yaptığı bir konuşmada Suriye konusunda hata yaptıklarını itiraf etmiş̧tir. ABD ve Batı ülkelerinin tavır değişimlerine karşın Türkiye'nin sürecin başında takınmış olduğu tavrı devam ettirmekte olduğu ifade edilebilir.

Liberal ve realist yaklaşım açısından genel bir değerlendirme yapılacak olursa özellikle ABD tarafının müzakereler ve diplomasiyi önceleyen liberal bir yaklaşım izlemek yerine Suriye meselesinde başta ekonomik yaptırım ve ambargo tehditleri olmak üzere realist yaklaşım araçlarına yöneldiği görülmektedir. Türk tarafi ise sürecin başında diplomasi ve müzakereleri önceleyen bir yaklaşım sergilemiş ancak bu kanaldan bir sonuç elde edemeyince askeri operasyonlar gerçekleştirmek zorunda kalmıştır. Askeri operasyonlar sonuç almak amacıyla sert etki araçlarına yönelinmesini içeren realist yaklaşım araçlarıdır.

ABD nispeten mikro bir sorun olarak değerlendirilebilecek Suriye meselesi nedeniyle başta Baltıklar, Gürcistan, Ukrayna, Afganistan gibi alanlar olmak üzere Türkiye'nin küresel iş birliği konularında verebileceği katkıları riske etmektedir. ABD dış politika yapıcılarının Türkiye'nin ne kadar değerli ve önemli bir ülke olduğu hususunu tekrar gözden geçirmeleri iki ülke ilişkileri üzerinde olumlu etki yapacaktır.

\section{KAYNAKÇA}

ALJAZEERA (2012), “Friends' of Syria Recognise SNC”, E-Doküman, https://www.aljazeera.com/news/middleeast/2012/04/20124113351659274.html (Erişim Tarihi: 09.12.2019).

ALJAZEERA (2014), “Türkiye - Suriye İlişkileri: İnişler ve Çıkışlar”, E-Doküman, http://www.aljazeera.com.tr/dosya/turkiye-suriye-iliskileri-inisler-ve-cikislar (Erişim Tarihi: 28.10.2019).

ANADOLU AJANSI (2018), “'Türkiye Meşru Müdafaa Hakkını Kullanıyor", E-Haber, https://www.aa.com.tr/tr/turkiye/turkiye-mesru-mudafaa-hakkini-kullaniyor/1042988 (Erişim Tarihi: 04.11.2020).

BBC (2019), “Barlş Pınarl Harekâtı: Türkiye ve ABD Anlaştı, Kim Ne Kazandt?”, E-Haber, https://www.bbc.com/turkce/haberler-dunya-50092778 (Erişim Tarihi: 02.11.2019).

CLINTON, Hillary (2014), Hard Choices, Simon and Schuster Publisher, New York (USA).

CRISIS GROUP (2013), "Syria's Kurds: A Struggle Within a Struggle", E-Doküman, https://www.crisisgroup.org/middle-east-north-africa/eastern-mediterranean/syria/syria-s-kurds-strugglewithin-struggle (Erişim Tarihi: 27.09.2019). 
DEMIR, Sertif ve KUDRET, Erkan (2019), "Türkiye-ABD Askeri İişskileri”, Türk - Amerikan İlişkileri (Ed. S. Demir, A. Eminoğlu), Barış Kitabevi, Ankara, ss.239-240.

DEUTSCHE WELLE (2018), “Türkiye'nin 7 Ylllık Suriye Politikası”, E-Doküman, https://www.dw.com/tr/t\%C3\%BCrkiyenin-7-y\%C4\%B111\%C4\%B1k-suriye-politikas\%C4\%B1/a42980399 (Erişim Tarihi: 29.09.2019).

ERDOĞAN, Recep Tayyip (2019), “Barış Pınarı Harekatı”, Twitter Sosyal Medya Paylaşımı, https://twitter.com/rterdogan/status/1181920482964250624 (Erişim Tarihi: 01.11.2019).

NTV (2019), "Eski Alman Bakan Açık Konuştu: Erdoğan'ın Suriye'de Uçuşa Yasak Bölge Talebi Hakliydı", Video Haber, https://www.ntv.com.tr/video/dunya/eski-alman-bakan-acik-konustu-erdoganin-suriyedeucusa-yasak-bolge-talebi-hakl,NN-caf421EWoJtWjHLJ6tw (Erişim Tarihi: 30.10.2019).

NTV (2019), "Suriye'de Üçüncü Harekât (Adım Adım Güvenli Bölgeye)", E-Haber, https://www.ntv.com.tr/turkiye/suriyede-ucuncu-harekat-adim-adim-guvenli-

bolgeye,vkFUytD0K0yXBLCDMl1pcg (Erişim Tarihi: 21.01.2020).

OYTUN, Orhan (2019), "Options for Turkey in Manbij and The East of The Euphrates River", E-Doküman, https://orsam.org.tr/en/options-for-turkey-in-manbij-and-the-east-of-the-euphrates-river/ (Erişim Tarihi: 29.09.2019).

STEIN, Aaron (2019), "The Crisis is Coming: Syria and The End of The U.S. - Turkish Alliance", E-Document, https://warontherocks.com/2019/08/the-crisis-is-coming-syria-and-the-end-of-the-u-s-turkish-alliance/ (Erişim Tarihi: 30.08.2019).

SZUBA, Jared (2019), "Turkey and US Agree to Jointly Administer Northern Syria Border Zone", EDocument, https://thedefensepost.com/2019/08/07/syria-turkey-border-zone-us/ (Erişim Tarihi: 29.09.2019).

T. C. MILLİ SAVUNMA BAKANLIĞI (2019), "Suriye Kuzeyinde Gerçekleşen İlk Müşterek Kara Devriyesi Hakkında Basın Açıklaması”, E-Doküman, https://www.msb.gov.tr/SlaytHaber/892019-64025 (Erişim Tarihi: 02.11.2019).

TBMM (2011), "Türkiye Cumhuriyeti Hükümeti ile Suriye Arap Cumhuriyeti Hükümeti Arasında Terör ve Terör Örgütlerine Karşı Ortak İşbirliği Anlaşmasının Onaylanmasının Uygun Bulunduğuna Dair Kanun Tasarısı", E-Doküman, https://www2.tbmm.gov.tr/d23/1/1-1009.pdf (Erişim Tarihi: 28.10.2019).

THE GUARDİAN (2014), “U. S. Drops Weapons and Ammunition to Help Kurdish fighters in Kobani”, EHaber, https://www.theguardian.com/world/2014/oct/20/turkey-iraqi-kurds-kobani-isis-fighters-us-airdrops-arms (Erişim Tarihi: 29.09.2019).

TRT WORLD (2016), “Timeline: Turkey's Fight with DAESH and YPG”, E-Document, https://www.trtworld.com/turkey/timeline-turkeys-challenge-with-daesh-pyd-171396 (Erişim tarihi: 29.09.2019).

YOUTUBE (2019), “ABD ile Kriz Aşıldı mı?, Ertelendi mi?”, Video Haber, https://www.youtube.com/watch?v=eUc7eVzqinY (Erişim tarihi: 17.11.2019)

YOUTUBE (2019), “After the Syrian Pullback: What Next for U.S. Middle East Policy?", E-Document, https://www.youtube.com/watch?v=_t_9m7UAmlI\&feature=youtu.be\&t=1112 (Erişim Tarihi: 31.10.2019). 